\title{
Tantangan Keuangan Islam di Era Four Point Zero (Islamic Finance Challenge in the Era of Four Point Zero)
}

\author{
Fahrurrozi*, Cici' Wilantini, Novita Tri Buana Dewi \\ Fakultas Ekonomi dan Bisnis Islam, Institut Agama Islam Negeri Madura, Indonesia
}

Globalization is a world development that removes barriers that make communication or interaction between countries difficult. With globalization there is a shift or industrial revolution from industry 3.0 to industry 4.0. with the existence of the revolution Islamic finance has several challenges that must be resolved immediately, some of the challenges facing Islamic finance in this industrial revolution consist of the banking sector, the zakat and waqf sector, the MSME development sector, the digital economy sector, the halal food and beverage product sector, the sector halal media and recreation, halal tourism sector, Muslim fashion sector, social security sector, sharia capital market sector, halal pharmaceutical and cosmetics sector.n

Keywords: Industrial Revolution, Globalization, Islamic Finance

OPEN ACCESS ISSN 2503-3077 (Online) (online) ISSN 2503-3077 (print)

${ }^{*}$ Correspondence: Fahrurrozi sahabatululalbab@gmail.com

Received: 21 August 2019 Accepted: 21 September 2019

Published: 30 October 2019

Citation:

F, Wilantini C and Dewi NTB (2019) Tantangan Keuangan Islam di Era Four Point Zero (Islamic Finance Challenge in the Era of Four Point

Perisai : Islamic Banking and Finance Journal. 3:2. doi: 10.21070/perisai.v3i2.2627
Globalisasi merupakan suatu perkembangan dunia yang menghilangkan batasanbatasan yang menyulitkan komunikasi atau interaksi antara negara satu dengan yang lainnya. Dengan adanya globalisasi inilah ada pergeseran atau revolusi industry dari industry 3.0 ke industry 4.0. dengan adanya revolusi tersebut keuangan Islam mempunyai beberapa tantangan yang harus segera diselesaikan, beberapa tantangan yang dihadapi keuangan Islam dalam revolusi industry ini terdiri dari sektor perbankan, sektor zakat dan wakaf, sektor pengembangan UMKM, sektor ekonomi digital, sektor produk makanan dan minuman halal, sektor media dan rekreasi halal, sektor pariwisata halal, sektor fesyen muslim, sektor jaminan social, sektor pasar modal syariah, sektor farmasi dan kosmetik halal.

Kata Kunci: Revolusi Industri, Globalisai, Keuangan Islam 


\section{PENDAHULUAN}

Selama beberapa dekade terakhir ini, kita telah menyaksikan perubahan dramatis dan cepat dalam struktur pasar dan institusi finansial di seluruh dunia. Kemajuan teori, langkah cepat inovasi finansial, revolusi teknologi informasi, deregulasi, dan reformasi institusional, telah mengubah karakter hubungan finansial dan muncul apa yang disebut sebagai "keuangan yang baru". Akibatnya: "orang dapat meminjam jumlah yang lebih besar dengan tingkat suku bunga yang lebih rendah daripada sebelumnya; dapat berinvestasi dalam beragam instrumen yang mencakup semua kemungkinan profil risiko dan pendapatan, dan berbagi risiko dengan orang asing dari belahan dunia lain. Berbagai perubahan ini telah mengubah karakter transaksi umum dalam sektor finansial, menjadikannya lebih cepat dan memungkinkan masuknya pelaku yang lebih beragam. Pasar finansial menjadi lebih luas dan lebih mendalam. Partisipasi yang luas memungkinkan risiko disebar dengan lebih luas dalam semua bidang ekonomi."

Keuangan yang baru memiliki peran penting mengembangkan bidang aktivitas ekonomi, dan karena itu berperan menjadi penyeimbang yang kuat dewasa ini: sistem tersebut tidak mensyaratkan paspor, dan tidak melakukan pembedaan atas dasar warna kulit, iman, ras, atau kewarganegaraan asal. Sistem tersebut terurai dan tidak terikat, terbagi-bagi, teranalisis, dan menghargai risiko dan mengeksplorasi semua peluang pernbagian risiko-keuntungan, sebagai upaya mengeksploitasi kemungkin an yang ada di antara tingkat pengembalian/pendapatan yang riil atas aset dengan tingkat suku bunga riil, yang menyebabkan ketergantungan yang lebih besar pada pembagian risiko Mirakhor and Iqbal (2008). Hal ini terjadi karena adanya perubahan cara atau terjadi pergeseran dalam sektor industry.

Pergeseran industry yang awalnya be rbasis kakuan pada industry yang menganut digitalisasi mengubah cara pandang Lembaga atau perorangan dalam melakukan transaksi keuangannya, hal dapat merusak dan mematikan industry yang tidak mau mengikuti arus global. Disamping itupula pergeseran industry tersebut mewajibkan para pelaku usaha untuk mengubah dan mengupdate cara berbisnisnya disinilah sistem keuangan Islam harus mengahadapi beberapa rintangan dan tantangan yang nantinya keuangan Islam bisa diterima oleh masyarakat.

\section{METODE PENELITIAN}

\section{Metodologi}

Metodologi penelitian yang dipakai untuk penulisan ini adalah metode kualitatif. Menurut Maleong (2000) penelitian kualitatif adalah penelitian yang menghasilkan data deskriptif baik tulisan maupun lisan yang didukung dengan studi literatur dan pendalaman kajian pustaka yang dapat dipahami baik menggunakan angka maupun data. Penelitian ini menggunakan pendekatan interpretif dan critical. Interpretif dilakukan untuk memberikan makna ( to interpret) dan memahami ( $t o$ understand ) pada sebuah aksi yang dilakukan oleh seseorang terhadap realitas sosial. Sedangkan prinsip critical mempunyai keyakinan bahwa manusia secara aktif akan merekonstruksi realitas sosialdan memberikan gambaran bahwa realitas sosial bukan diciptakan secara natural oleh alam, akan tetapi muncul akibat adanya interaksi manusia.

Dua metodologi yang digunakan oleh peneliti (metodologi kualitatif dengan pendekatan interpretif dan critical ) mempunyai tujuan agar dapat memberikan arti tentang menumbuhkembangkan karakter entrepreneurship pada generasi mileneal muslim dengan menggunakan pendekatan nilai-nilai ilahiyah yang penuh dengan transindental dan teologikal, peneliti mempunyai tujuan agar dapat memberikan konstribusi pemikiran yang bermanfaat terhadap generasi milenial muslim dalam menumbuh dan mengembangkan jiwa entrepreneur dengan berprinsip pada kaidah-kaidah dan moral keislaman dan menghindari integrasi dan dekadensi moral yang akhir-akhir ini banyak dialami oleh generasi-genarasi saat ini.

Pada penelitian ini peneliti menekankan pada datadata sekunder yang berupa kajian pustaka. Oleh sebab itu peneliti melakukan penelitian di dalam perpustakaan untuk mengumpulkan data-data yang terkait dengan jenis penelitian. Jenis penelitian yang digunakan adalah studi literatur, dimana studi literatur merupakan bentuk penelitian yang menggunakan literatur sebagai objek kajian. Literatur pada hakikatnya merupakan bentuk karya tulis yang diolah oleh budi manusia untuk menuangkan gagasan dan ide sekelompok orang sebagai pandangan hidup. Penelitian literatur bukan semata-mata dilakukan dengan buku semata akan tetapi juga di sesuaikan dengan hasil penelitian lapangan.

\section{Metode Pengumpulan Data}

Sesuai dengan metodologi penelitian yang digunakan, maka data yang digunakan adalah data sekunder yang didapatkan dengan mencari pokok-pokok pikiran yang ditulis oleh pemikir atau ilmuan yang telah ditulis dalam buku-buku, jurnal-jurnal terutama yang berkaitan dengan tema sentral yang telah diajukan.

\section{Metode Analisis Data}

Metode analisis yang digunakan dalam penelitian ini adalah metode analisis deskriptif dengan cara menyajikan data yang dihasilkan dari penelitian dan membandingkan dengan teoriteori yang ada, sehingga dapat ditarik kesimpulan dan didapatkan alternatif pemecahan masalah Maleong (2000).

Penggunaan analisis deskriptif dimaksudkan untuk memungkinkan peneliti membuat pengertian-pengertian secara dialektik berdasarkan hasil data yang dikumpulkan Sutopo (2002). Analisis penelitian ini juga dianalisis secara induktif ( Imprico Inductive) yaitu analisis data dengan cara mengumpulkan data terlebih dahulu dan harus dipahami sebagai modal dasar pemahaman Sutopo (2002) dan di analisis serta dideskripsikan dalam sebuah tulisan Maleong (2000).

Setelah melakukan pengumpulan data, maka analisis data dimulai dengan menelaah seluruh data yang tersedia dari berbagai sumber. adalah:

Adapun tahapan dalam analisis dalam penelitian ini

1. Mereduksi data, yaitu dengan menajamkan, menggolongkan, membuang data yang tidak perlu dan mengorganisasi data sehingga ditemukan sebuah kesimpulan akhir dan 
dapat ditarik kesimpilan serta diverifikasi.

2. Penyajian data, yaitu berupa sekumpulan informasi tersusun yang dapat memberikan kemungkinan adanya penarikan kesimpulan informasi dan pengambilan tindakan. Dengan penyajian data kita dapat memahami apa yang sedang terjadi dan apa yang harus dilakukan.

\section{HASIL DAN PEMBAHASAN}

\section{Revolusi industry $\mathbf{4 . 0}$}

Istilah Revolusi industry 4.0 merupakan sebuah masa dimana terjadi pertukaran dan trend otomasi dalam teknologi pabrik yang didalamnya mencakup sistem physical ciber yang menggunakan internet untuk segala komputasi awan dan komputasi kognitif. Revolusi industry 4.0 sangat berdampak pada persaingan ketat di berbagai bidang baik dibidang ekonomi, politik, pendidikan dan social budaya bahkan agama, hal ini dikarenakan revolusi industry 4.0 dilahirkan desrupsi secara massif. Munculnya desrupsi ini karena di pengaruhi beberapa hal yaitu, Tekhnologi, Generasi milenial, Microprosessor, Desrptive leader, Internet of things Adjie (2018), dan Perubahan mindset.

Renald Kasali menjelaskan bahwa respon terhadap revolusi industry 4.0 semakin hari semakin menunjukkan pertambahan besar bahkan pertambaannya tanpa batas seperti bola salju yang terus menggelending. The Great Discruption: Human Nature and the Reconstitution of social sebuah buku yang karang oleh Francis Fukuyama, memberikan penjelasan bahwa transformasi peradaban masyarakat berdampak luas terhadap perubahan social manusia dari peradaban konvensional menuju peradaban modern hal inilah yang disebut dengan dan the great disruption. Factor penyebab terjadinya transformasi peradaban ini dapat disebakan karena adanya kemiskinan, ketimpangan kekayaan, kemunculan klasifikasi Negara adidaya serta pergeseran budaya yang luas Fukuyama (2005). Bahkan Airlangga Hartanto sebagai menteri perindustrian Republik Indonesia menjelaskan bahwa revolusi industry 4.0 sejatinya sudah mulai sejak jaman Hindia-Belanda, ini dibuktikan dengan adanya industry pertama yang menggunakan mesin uap, revolusi industry 4.0 yang di awali dengan revolusi internet off things yang sudah dimulai pada tahun 90an. Pemanfaatan internet of things pertama kali dilakukan oleh Negara Jerman serta jerman pulalah yang memperkenalkan dan mengglobalkan istilah industry 4.0 Rachman (2018).

Revolusi industry 4.0 sangat cocok dengan generasigenerasi kekinian yang disebut dengan generasi milenial karena generasi milenial lebih mampu untuk menyesuaikan dan punya kemampuan dalam beradaptasi dengan target yang ditentukan perusahaan, keriteria yang dimiliki oleh generasi milenial adalah mampu memanfatkan media elektronik dalam berinteraksi dengan orang lain bahkan generasi milenial ini mempunyai sifat ambisius dan berani mengambil risiko dalam mewujudkan goal yang ditentukan oleh perusahaan Setiawan (2018), dengan adanya sifat seperti ini maka sewajarnya seorang pimpinan harus memberikan factor-faktor penyeimbang agar terwujud generasi yang mempunyai loyalitas yang tinggi dalam pekerjaan Setiawan et al. (2018).

Pada era revolusi industry 4.0 ini generasi milenial akan lebih mudah membangun jaringan persahabatan atau bis- nis tanpa batas, jaringan bisa dibentuk melalui media social seperti facebook, twiter, whatsup, line, mesegger dan yang lainnya, dimana jaringan persahabatan dan jaringan bisnis ini dapat dijadikan modal yang sangat berguna dalam melakukan kegiatan wirausaha.

Munculnya revolusi industry 4.0 tidak lepas dari adanya globalisasi dimana globalisasi merupakan proses multidimensional dari perkembangan ketersalin hubungan di antara berbagai bangsa dan banyak orang di dunia. dimensi utamanya adalah kultural, sossiopolitik, dan ekonomi. Dimensi ekonominya mencakup aliran perdagangan yang terus turnbuh, gerakan keuangan yang transparan, investasi dan produksi yang disertai dengan standarisasi proses, regulasi, dan institusi-semuanya difasilitasi oleh aliran bebas informasi dan ide. Globalisasi adalah hasil dari reduksi biaya informasi dan transportasi, serta liberalisasi perdagangan, keuangan, investasi, aliran kapital, dan gerakan berbagai macam faktor.

Ketika globalisasi mendapatkan momentumnya dan menjadi semakin menyebar luas, dan semakin banyak sisrem ekonomi yang diliberalisasikan sebagai upaya mengintegrasikan ekonomi global, mode keuangan baru akan tumbuh bersama dengan berkembangnya mode pembagian risiko dan sekuritas berbasis aset: keduanya merupakan inti sistem keuangan Islam; Globalisasi pada saat ini dianggap tidak adil karena risiko dan imbalan dari proses tersebut tidak dibagi sama rata. Walaupun demikian, seiring dengan tumbuhnya pendanaan berbasis ekuitas dan berbasis aset, hasil dari globalisasi dapat didistribusikan lebih luas dan lebih seirnbang di antara partisipannya ketimbang sebelumnya, paling tidak dari segi hubungan keuangan. Masih ada pertanyaan berkaitan dengan proteksionisme di negara industri, pasar tenaga kerja yang tersegmentasi, dan halangan untuk mentransfer teknologi, yang menuntut kerja sama internasional penuh.

Jika proses globalisasi pada saat ini ditandai dengan aliran bebas perdagangan, investasi, dan produksi, maka dimungkinkan untuk mengidentifikasikan episode globaliasi yang mirip dengan yang ada pada Abad Pertengahan. Sepanjang periods yang dikenal sebagai "masa revolusi komersial", para pedagang mengalir dengan bebas melintasi dunia, didukung oleh metode keuangan berbagi risiko, yang dikembangkan negara muslim yang konsisten dengan syariah. Informasi tentang ciri dasar metode ini ditransmisikan lewat intermediasi akademisi dan pedagang Yahudi, dan yang leblh penting, juga lewat Spanyol, dari dunia muslim ke Mesir, Eropa, India, dan Afrika Utara. Teknik keuangan baru ini juga ditransmisikan oleh Pedagang muslim ke Eurasia, Rusia, dan Cina, juga ke Timur Mirakhor and Iqbal (2008).

Seiring dengan berlanjutnya globalisasi, mesin utamanyasistem keuangan baru dan kemajuan dalam teknologi informasi-akan menggeser metode serta instrumen pendanaan perdagangan, investasi, dan produksi menuju ke penyebaran dan pembagian risiko yang Iebih besar ketimbang pengalihan risiko via kontrak utang bernilai tetap. Ini merupakan hasil inovasi finansial yang membedah, menganalisis, dan melakukan penilaian risiko dengan lebih baik, sehingga dikombinasikan dengan ketersediaan informasi yang efisien dan pengadopsian standar transparansi, akuntabilitas, dan tata kelola perusahaan internasional dalam sekt or publik maupun swasta-mison d'etre kontrak utang bernilai tetap akan terkikis. 


\section{Perkembangan Sistem Keuangan Islam}

Proses perkembangan keuangan Islam dapat ditelusuri mulai era Nabi Muhamamd Saw. Ketika itu doktrin mengenai operasi keuangan langsung dari al-Qur ' an dan Hadits, pada masa itu metode keuangan langsung dipraktikan oleh beliau seperti pelaksanaan kontrak dengan menggunakan akad mudarabah dengan Siti Khadijah dimana Nabi Muhammad Saw berperan sebagai agen, selain itu, Nabi Muhammad Saw juga memperbolehkan penjualan tangguh yang dipraktikan di Madinah.

Selanjutnya keuangan Islam muncul bertahap di panggung internasional sejak tahun 1970-an dimana penyebab kemunculannya dikarenakan adanya persepsi masyarakat muslim untuk memulihkan ekonomi yang dihancurkan oleh sistem keuangan kapitalis dan sosialis. Pada tahun itu pula banyak bermunculan organisasi-organisasi keuangan berbasis Islam salah satunya adalah terbentuknya Islamic Development Bank (IDB) setelah itu muncul juga Islamic Financial Institutions,sebagian besar organisasi-organisasi keuangan muncul di Mesir, Sudan, Pakistan, Iran dan lain sebagainya.Pada tahun 2000-an didirikanlah International Islamic Liquidity Management Corporation (IILM) dengan tujuan meningkatkan kemampuan manajemen likuiditas dan untuk menerbitkan instrument-instrument keuangan jangka pendek yang penuh syariah, Indonesia dan Negara-negara lainnya menjadi pemegang saham sekaligus pendiri dari organisasi ini Dusuki (2015).

Saat ini perkembangan keuangan Islam semakin maju, hal ini dibuktikan dengan munculnya beberapa lembaga keuangan yang berbasis syariah serta penggunaan lembaga tersebut sudah mulai diakui oleh masyarakat.

\section{Tantangan Sistem Keuangan Islam}

Ada beberapa tantangan keuangan Islam yang harus segara di selesaikan agar keuangan Islam bisa berbicara banyak di sektor ekonomi dunia, tantangan-tantangan tersebut dibagi dalam beberapa sektor:

\section{Sektor perbankan}

Perbankan merupakan sektor unggulan dalam sistem keuangan Islam, tantangan klaster perbankan ini diidentifikasi dari beberapa sudut pandang, pertama kurangnya tenaga kerja yang spesifik menguasai industry perbankan syariah, kedua kebijakan yang dikeluarkan oleh pemerintah dan otoritas terkait belum terintegrasi dan tersinergikan dengan sempurna serta belum adanya keselarasan visi dan misi yang dibuat antar depertemen atau regulator, ketiga kurangnya akademisi terkait dengan industry perbankan syariah, ketiga penetrasi pada sektor perbankan syariah serta kesadaran masyarakat terkait dengan perbankan syariah masih rendah, keempat bank umum syariah kualitas teknologi masih kalah dengan teknologi bank konvensional serta kurang memanfaatkan financial technology sehingga perbankan syariah kurang menyentuh pada kalangan generasi milenial.

\section{Sektor zakat dan wakaf}

Zakat dan wakaf merupakan instrument keuangan Islam yang layak di kembangkan, Indonesia mempunyai potensi sangat besar pada sektor ini hal ini dikarenakan Indonesia mempunyai keunggulan dari segi jumlah penduduk yang may- oritas beragama Islam. Beberapa tantangan yang di hadapi dalam klaster ini diantaranya, pertama, masih terbatasnya pengetahuan dan kesadaran masyarakat mengenai zakat dan wakaf terutama wakaf tunai, kurang optimalnya penggunaan teknologi dalam zakat terutama pada BAZNAS dan LAZ tingkat daerah serta pemanfaatan teknologi tersebut belum dilakukan secara optimal seperti layanan multipayment dan $e$ commerce dan yang tidak kalah penting adalah belum adanya pusat kajian strategis BWI. Kedua dari segi regulasi dan kelembagaan, masih kurangnya aturan-aturan teknis untuk menjalankan regulasi terkait zakat seperti regulasi audit lembaga zakat, masih terbatasnya peran dan dukungan untuk Badan Wakaf Indonesia serta masi terbatasnya kelembagaan pendukung termasuk sinergi dan harmonisasi antar berbagai lembaga terkait zakat. Ketiga rendahnya kualitas dan kuantitas SDM terkait dengan pengelolaan zakat dan wakaf.

\section{Sektor pengembangan UMKM}

UMKM memiliki kontribusi yang sangat besar terhadap perekonomian Indonesia. Pemerintah sudah mempunyai rencana yang matang dalam pengembangan UMKM, pemerintah juga sudah menempatkan UMKM menjadi sektor yang sangat diperhitungkan akan tetapi ada beberapa tantangan yang dapat menghambat pengembangan UMKM, seperti kemampuan ekspor UMKM Indonesia masih rendah, sepertiga UMKM di Indonesia masih belum berbasis teknologi, minimnya infrastruktur di sekitar kegiatan usaha, kurangnya SDM pengawasan halal dari hulu ke hilir, sulitnya mencari mentor untuk pendampingan dan pembiayaan bisnis.

\section{Sektor ekonomi digital}

Ekonomi digital merupakan termenologi baru, ASEAN Investment report mendefinisikan ekonomi digital sebagai aplikasi teknologi menggunakan internet dalam produksi dan perdagangan jasa. Dalam kaitannya dengan ekonomi Islam digital ( Islamic digital ecconomy) saat ini belum ada definisi yang disepakti secara global akan tetapi definisi yang sudah biasa di sampaikan oleh para pakar, ekonomi Islam digital adalah bagian dari ekonomi Islam yang mendukung industry halal melalui e-commerce yang baik. saat ini perkembangan teknologi dalam kegiatan ekonomi islam sudah ada perkembangan signifikan hal ini terbukti dengan adanya fintech yang semakin subur, akan tetapi ada tantangan yang di hadapi dari semakin suburnya fintech, diantaranya adanya ketimpangan eksprosur terhadap teknologi digital antara pedesaan dan perkotaan, biaya dan akses internet masih relati mahal, masih minimnya pendidikan ekonomi digital, harmonisasi regulasi dan koordinasi antar lembaga masih rendah dan mencuatnya isu cybercrime dan cyberattack.

\section{Sektor produk makanan dan minuman halal}

Pengembangan industry makanan dan minuman halal harus terjaga mulai dari bahan baku sampai produk jadi yang siap di konsumsi. Beberapa tantangan yang diadapi pada klaster ini, pertama akses pasar internasional masih relative kecil ditambah lagi dengan minimnya riset pasar, segmentasi serta selera pasar, kedua lembaga-lembaga keuangan masih kurang memahami seluk beluk industry kreatif serta masih dianggap 
rumit oleh pelaku usaha untuk pengajuan pembiayaan, ketiga kurangnya riset tentang uji bahan pangan halal dan terbatasnya database industry makanan dan minuman halal karena masih rendahnya pemanfaatan teknologi informasi ditambah lagi dengan masih adanya asyimmitric information antar sektor.

\section{Sektor media dan rekreasi halal}

Indonesia merupakan salah satu Negara yang diperhitungkan dalam sektor pemberdayaan media dan rekreasi halal. Industry aplikasi digital (apps) belakangan ini menjadi primadona terutuma bagi kalangan generasi milineal sehingga bisa menyumbang penurunan angka pengangguran, subsector ini diprediksi akan terus berkembang, dengan adanya hal ini maka tantangan yang dihadapi berupa, pertama masih kurang memadainya koneksi internet yang merata diberbagai daearah ditambah lagi biaya internet masih mahal, kedua belum adanya regulasi khusus tentang media dan rekreasi halal serta lembaga keuangan belum melirik sektor media dan rekreasi halal ini.

\section{Sektor pariwisata halal}

Pariwisata merupakan sektor yang berpotensi di dunia karena bisa meningkatkan pendapatan devisa Negara, penyerapan tenaga kerja, dan pengembangan usaha serta infrastruktur, berbagai tantangan yang harus dilalui agar pariwisata halal bisa lebih maju, diantaranya pertama, berkembangnya pariwisata halal di Negara-negara muslim tidak diimbangi dengan kualitas sarana prasana pariwisata halal serta masih lemahnya branding pariwisata halal berskala internasional, kedua, beluem tersedianya produk hukum yang mengatur kewajiban lembaga keuangan untuk memberikan pembiayaan terhadap pariwisata halal, ket iga kurangnya riset tentang pariwisata halal serta belum adanya kurikulum pariwisata halal pada tingkat nasional, keempat kurang memanfaatkan kemajuan tekhnologi dalam mendukung berkembangnya pariwisata halal.

\section{Sektor fesyen muslim}

Saat ini industry fesyen muslim menjadi subsector ekonomi kreatif, hal tersebut tidaklah mengerankan dikarenakan fesyen muslim menjadi trending saat ini, ditambah lagi komposisi penduduk di Indonesia yang lebih banyak yang muslim. Keunggulan ini harus menjadi peratian serius dari para pemangku kepentingan, ada tantangan yang dihadapi dalam pengembangan fesyen muslim, yaitu pertama masih kalah dengan brand barat yang sudah mapan serta akses pasar internasional terhadap fesyen muslim masih rendah dan produk fesyen muslim dari cina dengan harga kompetitif, kedua kurangnya pemanfaatan teknologi dalam pengembangan fesyen muslim ditambah lagi dengan adanya regulasi yang sinkron antara pemerintah pusat dengan daerah. ketiga lembaga keuangan masih menomorduakan sektor fesyen muslim ini dan/atau masih memberikan syarat yang rumit dalam pengajuan pembiayaan fesyen muslim serta kurangnya riset tentang fesyen muslim.

\section{Sektor jaminan sosial}

Security seperti didefinisikan oleh Asosiasi Jaminan sosial internasional (ISSA) merupakan program proteksi sosial yang disahkan melalui proses legislasi, atau peraturan mandatori lainnya, yang menyediakan para individu dengan suatu derajat keamanan penghasilan ketika berhadapan dengan kontingensi usia tua, survivorship, incapacity, cacat fisik (disability), pengangguran ( unemployment), atau mengasuh anak ( rearing children ). Dalam definisi ISSA, jaminan sosial dapat meliputi program asuransi sosial ( jaminan sosial), program bantuan sosial ( social assistance ), universal programmes, mutual benefit schemes, national provident funds, dan bentuk-bentuk lain yang disesuaikan dengan perkembangan di setiap negara.

Perkembangan jaminan sosial negara-negara di dunia dapat dilihat dari 3 hal, yaitu comprehensive jaminan sosial coverage, program-program yang berdampak secara sosial dan ekonomik, serta administrasi dan manajemen yang efektif dan efisien. Di Eropa, ketiga hal tersebut mengalami perkembangan karena merespons lingkungan eksternal berupa tekanan masyarakat yang meningkat yang meliputi penuaan demografis ( demographic ageing), meningkatnya penyakit kronis, dan pengaruh krisis finansial dan ekonomi 2008/2009.

Indonesia memiliki Undang-Undang (UU) Nomor 40 Tahun 2004 Tentang Jaminan Sosial sebagai salah satu bentuk perlindungan untuk menjamin seluruh rakyat agar dapat memenuhi kebutuhan dasar hidupnya yang layak. Akses terhadap jaminan sosial merupakan hak bagi setiap warga negara untuk mewujudkan masyarakat Indonesia yang sejahtera, adil, dan makmur. Jenis perlindungan social meliputi jaminan kesehatan, jaminan kecelakaan kerja, jaminan hari tua, jaminan pensiun, dan jaminan kematia n. Tantangan yang dihadapi seperti, Persebaran geografis yang luas dengan variasi level pengetahuan tentang konsep asuransi syariah serta indeks literasi yang masih rendah, Initial cost untuk investasi teknologi yang masih tinggi, belum adanya regulasi yang mewajibkan institusi jaminan social dalam hal pengembangan skema syariah dalam produknya..

\section{Sektor pasar modal syariah}

Pasar modal syariah merupakan salah satu sektor dalam industry keuangan syariah yang berfungsi intermediasi sirkulasi modal, secara umum industry pasar modal syariah mencakup penerbitan saham syariah, sukuk dan reksadana syariah. Dalam pengembanganya ada beberapa tantangan yang harus diselesaikan seperti, masih kurangnya ketegasan dari pihak terkait piak-pihak yang tidak patuh teradap regulasi yang sudah ditentukan, belum optimalnya pemerintah dalam mencari potensi pengembangan infrastruktur dan fasilitas sektor halal industri di setiap daerah Indonesia yang merupakan potensi masuknya pasar modal dalam sektor pembiyaan melalui sukuk, perkembangan teknologi akan menjadi ancaman serius apabila tidak difungsikan dengan baik, integrasi ASEAN dan MEA akan menjadi ancaman teradap perkembangan industry pasar modal syariah jika fondasi dan infrastruktur keuangan tidak perkuat oleh shareholder dan stakeholder terkait. 


\section{Sektor farmasi dan kosmetik halal}

Farmasi dan kosmetik halal merupakan produk yang terbuat dari bahan aku yang sesuai dengan anjuran syariah Islam, kandungan yang ada pada bahan baku farmasi dan kosmetik halal bebas dari unsur binatang yang diharamkan dan yang disembelih tidak sesuai dengan aturan syariah Islam. Komoditas ini harus diproduksi dan diproses dengan menggunakan alat yang tidak tercampur dengan zat yang tidak sesuai dengan syariah, dengan demikian farmasi dan kosmetik halal ini menjadi good manufacturing practice. Ada beberapa tantangan yang dihadapi dalam pengembangan farmasi dan kosmetik halal ini yaitu:

1. Akses pasar internasional masih minim

2. Kurangnya riset tentang pergerakan, segmen dan selera pasar

3. Tingginya ketergantungan industry teradap bahan baku impor

4. Belum adanya panduan dan ketentuan untuk infrastruktur yang menunjang produksi farmasi dan kosmetik halal

5. Masih ribetnya pengurusan pembiayaan pada lembaga keuangan

6. Terbatasnya ketersediaan database industry farmasi

7. Pemanfaatan teknologi pada industry farmasi dan kosmetik halal masih rendah

\section{REFERENCES}

Adjie, A. W. (2018). Bedah Buku Discruption 170430165621.pdf. (Accessed on 2018-09-20).

Dusuki, A. W. (2015). Sistem Keuangan Islam; Prinsip dan Operasi (Jakarta: PT Graindo Persada).

Fukuyama, F. (2005). The Great Disruption: Human Nature and the Reconstitution of Social Order. Translation: Masri Maris (Jakarta: PT Gramedia Pustaka Utama).

Maleong (2000). Metode penelitian kualitatif (Bandung: PT . Remaja Rosda Karya).

Mirakhor, A. and Iqbal, Z. (2008). Pengantar Keuangan Islam: Teori Dan Praktik (Jakarta: Kencana).

Rachman, F. F. (2018). Apa Itu Revolusi Industri 4.0? detik.com. https://finance.detik.com/industri/d-3952668/apa-itu-revolusi-industri-40. (Accessed on 2018-09-29)

Setiawan, W. (2018). Reward and Punishment dalam Perspektif Pendidikan Islam. AL MJURABBI 4, 184-201.

\section{KESIMPULAN}

Revolusi industry 4.0 merupakan sebuah masa dimana terjadi pertukaran dan trend otomasi dalam teknologi pabrik yang didalamnya mencakup sistem physical ciber yang menggunakan internet untuk segala komputasi awan dan komputasi kognitif, dimana dengan adanya revolusi industry 4.0 akan berdampak pada persaingan ketat di berbagai bidang baik dibidang ekonomi, politik, pendidikan dan social budaya bahkan agama, hal ini dikarenakan revolusi industry 4.0 dilahirkan desrupsi secara massif. Munculnya desrupsi ini karena di pengaruhi beberapa hal yaitu, Tekhnologi, Generasi milenial, Microprosessor, Desrptive leader, Internet of things Adjie (2018), dan Perubahan mindset.

Tantangan yang dihadapi terdiri dari 11 sektor yaitu sektor perbankan, sektor zakat dan wakaf, sektor pengembangan UMKM, sektor ekonomi digital, sektor produk makanan dan minuman halal, sektor media dan rekreasi halal, sektor pariwisata halal, sektor fesyen muslim, sektor jaminan social, sektor pasar modal syariah, sektor farmasi dan kosmetik halal.

Setiawan, W. et al. (2018). Pendidikan Kebahagiaan dalam Revolusi Industri 4 5, $101-120$.

Sutopo (2002). Metodologi Penelitian Kualitatif (Surakarta: UNS Press).

Conflict of Interest Statement: The authors declare that the research was conducted in the absence of any commercial or financial relationships that could be construed as a potential conflict of interest.

Copyright (c) 2019, Wilantini and Dewi. This is an open-access article distributed under the terms of the Creative Commons Attribution License (CC BY). The use, distribution or reproduction in other forums is permitted, provided the original author(s) and the copyright owner(s) are credited and that the original publication in this journal is cited, in accordance with accepted academic practice. No use, distribution or reproduction is permitted which does not comply with these terms. 